\title{
Effects of Diets Containing Beta-Glucan on Survival, Growth Performance, Hematological, Immunity and Biochemical Parameters of Rainbow Trout (Oncorhynchus Mykiss) Fingerlings
}

Mohammad Hossein Khanjani ( $\sim$ m.h.khanjani@gmail.com )

University of Jiroft https://orcid.org/0000-0002-3891-8082

Gholamreza Ghaedi

Khorramshar Marine Science and Technology University: Khorramshahr Marine Science and Technology University

Moslem Sharifinia

Iranian Fisheries Research Organization

\section{Research Article}

Keywords: Beta-glucan, Immune-stimulation, Rainbow trout, Growth performance, Innate immunity

Posted Date: August 12th, 2021

DOl: https://doi.org/10.21203/rs.3.rs-641367/v1

License: (c) (1) This work is licensed under a Creative Commons Attribution 4.0 International License.

Read Full License 


\section{Abstract}

This study aimed to investigate the effect of beta-glucan in rainbow trout's diet on survival, growth performance, hematological, immunity and biochemical parameters. Rainbow trout (Oncorhynchus mykiss) with an average weight of $6.35 \pm 0.09$ were stocked in 30 fiberglass tanks with a volume of 200 liters. Four treatments including: control group ( $0 \%), 0.5,1$ and $2 \%$ of beta-glucan were considered for 8 weeks. The results showed that the survival and growth performance of rainbow trout in the control group were at the lowest level and showed a significant difference with other treatments. The highest percentage of hematocrit (47.9\%), white blood cell count, neutrophil percentage (35.2\%) was observed in

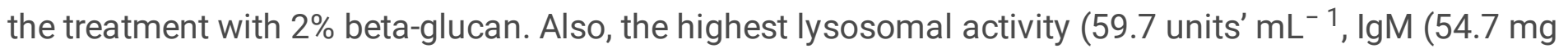
$\mathrm{dL}^{-1}$ ), C3 and C4 was obtained in $2 \%$ beta-glucan treatment. Biochemical parameters showed improvement in treatments fed with 1 and $2 \%$ beta-glucan. In general, the present study showed that $2 \%$ beta-glucan in the diet of rainbow trout improves growth performance, survival, hematological, immunity and biochemical parameters.

\section{Introduction}

The aquaculture industry as one of the sources of protein and significant source of sustainable food is growing rapidly (Khanjani et al. 2021d; Khanjani and Sharifinia 2020,). Success in aquaculture is achieved by improving genetics, nutrition, immunity and disease control in farmed species. Parameters such as specific growth rate, feed conversion ratio and survival rate play a key role in evaluating an aquaculture system (Ghaedi et al. 2015, Khanjani et al. 2020b). The use of immunostimulants is considered as an effective tool to overcome diseases and strengthen the immune system of farmed organisms (Meena et al., 2013). In recent decades, much attention has been paid to finding a variety of immunostimulants with low cost which affect specific and nonspecific immunity and improve the resistance of fish to a wide range of pathogens (Ghaedi et al. 2015, Dawood et al. 2020a, Mokhbatly et al. 2020, Yang et al. 2021). These stimuli strengthen the immune system of fish by increasing the number of phagocytes, enhancing the activity of lysozyme, complement and rising the level of immunoglobulin (Dawood et al. 2020b, Yan et al. 2020).

Recently, more attention has been paid to the use of functional dietary supplements such as probiotics, prebiotics and immune stimulants in aquaculture. These compounds are useful for improving the immune system, feed efficiency and fish growth performance. Among these immunostimulants used in aquaculture, beta-glucans are of particular importance for use in the aquaculture industry, as these compounds reduce stress, disease prevalence, and fish production through biotechnology (Pilarski et al. 2017). $\beta$-glucans are homopolysaccharides which composed of glucose molecules linked together by a glycosidic bonds. This immunostimulant has been widely used to boost innate immunity, and to improve phagocyte activity, respiratory burst activity, nitric oxide, complement and lysozyme activity; it also enhances the number of leukocytes (Soltanian et al. 2009, Meena et al. 2013) in some species such as grass carp (Yang et al. 2021); African catfish (Mokhbatly et al. 2020); pearl gentian grouper (Wei et al. 2020); rainbow trout (Ji et al. 2020) and Nile tilapia (Dawood et al. 2020a). In nature, $\beta$-glucans are 
abundant in the cell wall of many plants such as wheat, rye, barley, oats, yeast (Saccharomyces) and members of the Echinaceae family (Tokunaka et al. 2000). $\beta$-glucans due to their ability to bind directly to macrophages and other white blood cells, such as neutrophils and natural killer cells, and activate them, they provide good resistance to any invader (Herre et al. 2004).

Rainbow trout (Oncorhynchus mykiss) is one of the most valuable economic fish and the most important cold-water species in Iran's aquaculture industry. Efforts to improve the growth indices and boost the immunity of this fish against various bacterial diseases have increased (Ranjbar et al. 2010). In several studies, the effects of various immunostimulants such as nettle (Nigella sativa), mistletoe (Viscum album), aloe vera (Aloe barbadensis), astragalus (Astragalus gummifer), Purple Coneflower (Echinacea purpurea), Oregano (Mentha longifolia), Green tea (Camellia sinensis), ginger (Zingiber officinale), Bakhtiari savory (Satureja bakhtiarica) and peppermint (Mentha piperita) have been used in rainbow trout (Haghighi and Sharif Rohani, 2013; Sheikhzadeh et al., 2011). The aim of the present study was to evaluate the effects of different concentrations of dietary $\beta$-glucan on growth performance, hematological, immunity and biochemical parameters of rainbow trout.

\section{Materials And Methods}

\subsection{Fish and experimental conditions}

Altogether, 360 rainbow trout fingerlings were obtained from a private company (Sepidan, Fars, Iran). Twelve 200-L tanks were prepared and 30 fish were stocked in each tank. water flow rate was $8.2 \mathrm{~L} \mathrm{~min}^{-}$

1. Water temperature $\left({ }^{\circ} \mathrm{C}\right), \mathrm{pH}$ and dissolved oxygen $\left(\mathrm{mg} \mathrm{L}^{-1}\right)$ were measured weekly and the levels were determined $12-13.4^{\circ} \mathrm{C}, 7-7.4$ and $7-7.6 \mathrm{mg} \mathrm{L}^{-1}$, respectively. Fish were distributed into four treatments with three replications for each treatment. The adaptation period was 2 weeks and the feeding was performed with the commercial diet. Light cycle was 12L:12D, and throughout the experiment, fish were fed four times daily to apparent satiation at 07:00, 11:00, 15:00 and 19:00 h for 8 weeks.

\subsection{Experimental diets}

$\beta$-glucan (MacroGard®, Biotec-Mackzymal, Troms $\emptyset$, Norway) was purchased and added to a commercial diet (Beyza Feed Mill, Fars province, Iran) to obtain diets containing $0.5,0.1 \%$ and $0.2 \% \beta-1,3 / 1,6$ yeast glucan. The diet contained $45 \%$ protein, $14 \%$ lipid and $15 \%$ carbohydrates. The prepared diets were stored at $4^{\circ} \mathrm{C}$ in plastic bags until used.

\subsection{Growth performance and survival}

Feeding was stopped $24 \mathrm{~h}$ before weighing. fish were anesthetized with clove powder at a concentration of $200 \mathrm{mg} \mathrm{L}^{-1}$.

Weight gain (WG), feed conversion ratio (FCR), specific growth rate (SGR) and survival rate were calculated using the standard formulas (Khanjani et al. 2021a, Khanjani et al. 2021b): 
Body weight gain $(\mathrm{g})$ = final weight- initial weight

Body weight index $(\mathrm{BWI})(\%)=[($ final weight- initial weight $) /$ initial weight $] \times 100$

Growth rate $(\mathrm{GR})(\mathrm{mg})=[($ final weight- initial weight)/ days of experiment $]$

Survival rate $(\mathrm{SR})(\%)=$ (number of individuals at end of testing period/initial number of

individuals stocked) $\times 100$.

Specific growth rate $(S G R)(\% /$ day $)=[($ In final weight-In initial weight $) \times 100] /$ days of experiment

Feed conversion ratio $(\mathrm{FCR})=$ feed consumed (dry weight)/live weight gain (wet weight)

\subsection{Sampling}

Sampling was performed 56 days after feeding with beta-glucan. First, the fish were anesthetized with cloves at a concentration of $200 \mathrm{mg} \mathrm{L}^{-1}$ and blood was taken from caudal vein (Bohlouli et al., 2015). Some blood was transferred to tubes containing heparin anticoagulant to measure hematological parameters and some was transferred to heparin-free tubes to prepare serum and to measure immunity and biochemical parameters. Heparin-free tubes were centrifuged at $5000 \mathrm{rpm}$ for 5 minutes to separate serum at $4^{\circ} \mathrm{C}$. Serum samples were transferred by sampler to Eppendorf vials and stored in a freezer at $-20^{\circ} \mathrm{C}$ until biochemical analysis was initiated (Chebanov and Billard 2001, Ghaedi et al. 2015).

\subsection{Hematological and biochemical analyses}

Blood was diluted and stained with Natt-Herrick's solution, then red blood cell (RBC) and white blood cell (WBC) measurement were performed by cell counter method. For differential counts of WBC, blood was spread on a slide and stained with Gimsa (Hrubec et al. 2001). Hct and $\mathrm{Hb}$ were measured by photometric assay of microhaematocrit and cyanomethemoglobin method, respectively (Houston 1990). Mean corpuscular volume (MCV), mean corpuscular haemoglobin $(\mathrm{MCH})$ and mean corpuscular haemoglobin concentrations (MCHC) were calculated by standard formulas (Ranzani-Paiva et al. 2004). Total protein was measured using a diagnostic kit (ZiestChem, Diagnostics Co., Iran) according to Vella (1986). Albumin content was determined following the method of Doumas et al. (1997). Globulin content was calculated by subtracting albumin from the total protein (Kumar et al., 2005).

\subsection{Immunological parameters}

The volume of serum complement producing $50 \%$ hemolysis (ACH50) was assayed using the method of Sunyer and Tort (1995). Lysozyme activity was determined according to the lysis of the lysozyme sensitive Gram-positive bacterium, Micrococcus lysodeikticus (Sigma) (Demers and Bayne 1997). Total immunoglobulin (Ig) level was determined in plasma prior to and after precipitating the Ig molecules employing a $12 \%$ solution of polyethylene glycol (Sigma Chemical) (Puangkaew et al. 2004). Immunoglobulin M (IgM) was measured using a protein kit (Pars Azmoun Company, Karaj, Iran) and the 
Bradford method (Kruger 2009). Measurement of alternative complements (C3 and C4) activity was performed based on rabbit red blood cell hemolysis (Amar et al. 2000).

\subsection{Statistical analysis}

Results were expressed as means \pm standard deviation (SD). SPSS software version 21 (SPSS, Chicago, IL, USA) was used to analyze the data. Kolmogorov-Smirnov and Levene's tests were used to check normality and variances for homogeneity, respectively. Then, one-way ANOVA test was applied to determine differences between hematological and immunological parameters at various levels of $b$ glucan. Tukey's post hoc test was applied to identify treatments with significant differences $(P<0.05)$.

\section{Results}

The results of rainbow trout growth performance are presented in Table 1. The results showed that the lowest rate of body weight gain, specific growth rate and growth rate were obtained in the control group $(P<0.05)$, higher values of these factors were observed in the $2 \%$ beta-glucan treatment. The highest rate of feed conversion ratio (1.19) was observed in the control group which showed a significant difference with other treatments $(P<0.05)$.

Table 1

Growth performance and survival rate of rainbow trout fed diets containing different levels of beta-glucan for 8 weeks

\begin{tabular}{|lllll|}
\hline Parameters & Control & $\mathbf{0 . 5 \%}$ & $\mathbf{0 . 1 \%}$ glucan & $\mathbf{0 . 2 \%}$ glucan \\
\hline Initial weight (g) & $6.34 \pm 0.1$ & $6.35 \pm 0.09$ & $6.32 \pm 0.08$ & $6.31 \pm 0.09$ \\
\hline Final weight (g) & $15.55 \pm 0.59^{\mathrm{c}}$ & $16.56 \pm 0.25^{\mathrm{b}}$ & $17.38 \pm 0.27^{\mathrm{a}}$ & $17.58 \pm 0.61^{\mathrm{a}}$ \\
\hline WG (g) & $9.21 \pm 0.59^{\mathrm{c}}$ & $10.21 \pm 0.25^{\mathrm{b}}$ & $11.06 \pm 0.27^{\mathrm{a}}$ & $11.27 \pm 0.61^{\mathrm{a}}$ \\
\hline SGR (\% day $\mathbf{- 1})$ & $1.6 \pm 0.06^{\mathrm{c}}$ & $1.71 \pm 0.03^{\mathrm{b}}$ & $1.8 \pm 0.03^{\mathrm{a}}$ & $1.82 \pm 0.06^{\mathrm{a}}$ \\
\hline GR (g day $\mathbf{- 1})$ & $0.164 \pm 0.011^{\mathrm{c}}$ & $0.182 \pm 0.01^{\mathrm{b}}$ & $0.197 \pm 0.005^{\mathrm{a}}$ & $0.2 \pm 0.01^{\mathrm{a}}$ \\
\hline BWI (\%) & $145.3 \pm 9.29^{\mathrm{c}}$ & $160.8 \pm 3.94^{\mathrm{b}}$ & $175.0 \pm 4.25^{\mathrm{a}}$ & $178.6 \pm 9.6^{\mathrm{a}}$ \\
\hline SR (\%) & $94.44 \pm 1.72^{\mathrm{b}}$ & $95.57 \pm 1.8^{\mathrm{b}}$ & $97.78 \pm 3.44^{\mathrm{a}}$ & $98.89 \pm 1.72^{\mathrm{a}}$ \\
\hline FCR & $1.19 \pm 0.07^{\mathrm{c}}$ & $1.08 \pm 0.03^{\mathrm{b}}$ & $0.99 \pm 0.02^{\mathrm{a}}$ & $0.98 \pm 0.05^{\mathrm{a}}$ \\
\hline Means in the same row with different superscripts are significantly different $(\mathrm{P}<0.05)$. \\
\hline
\end{tabular}

Blood parameters of rainbow trout fed with different levels of beta-glucan is presented in Table 2 . According to the results, the highest white blood cell density and hematocrit percentage $(47.9 \%)$ were observed in the treatment of trout fed with $2 \%$ beta-glucan $(P<0.05)$. 
Table 2

Hematological parameters (mean $\pm S D$ ) of rainbow trout fed with different levels of $\beta$-glucan for 8 weeks.

\begin{tabular}{|c|c|c|c|c|}
\hline Parameters & Control & $0.5 \%$ & $0.1 \%$ glucan & $0.2 \%$ glucan \\
\hline $\mathrm{RBC}\left(\times 10^{6} \mathrm{~mm}^{-3}\right)$ & $0.9 \pm 0.1^{c}$ & $1.02 \pm 0.13^{a b c}$ & $1.04 \pm 0.1^{\mathrm{ab}}$ & $1.15 \pm 0.23^{\mathrm{a}}$ \\
\hline $\mathrm{HB}\left(\mathrm{g} \mathrm{dL}^{-1}\right)$ & $6.95 \pm 0.18^{d}$ & $7.35 \pm 0.3^{c}$ & $7.95 \pm 0.33^{b}$ & $8.45 \pm 0.22^{\mathrm{a}}$ \\
\hline HCT (\%) & $35.35 \pm 1.23^{c}$ & $40.05 \pm 2.13^{b}$ & $41.75 \pm 4.5^{\mathrm{b}}$ & $47.9 \pm 2.0^{\mathrm{a}}$ \\
\hline MCV (fL) & $392.77 \pm 12.2^{b}$ & $392.7 \pm 14.1^{b}$ & $401.44 \pm 19.3^{\mathrm{ab}}$ & $416.52 \pm 17.1^{a}$ \\
\hline $\mathrm{MCH}(\mathrm{pg})$ & $77.22 \pm 1.5^{\mathrm{a}}$ & $72.06 \pm 2.7^{b}$ & $76.44 \pm 3.13^{\mathrm{ab}}$ & $73.48 \pm 3.2^{b}$ \\
\hline $\mathrm{MCHC}\left(\mathrm{g} \mathrm{dL}^{-1}\right)$ & $19.66 \pm 0.5^{\mathrm{a}}$ & $19.34 \pm 0.6^{a}$ & $19.05 \pm 0.53^{a}$ & $19.25 \pm 0.63^{\mathrm{a}}$ \\
\hline WBC $\left(\times 10^{3} \mathrm{~mm}^{-3}\right)$ & $8.75 \pm 0.53^{c}$ & $8.85 \pm 0.43^{c}$ & $9.65 \pm 0.31^{b}$ & $10.45 \pm 0.44^{a}$ \\
\hline Neutrophils (\%) & $29.05 \pm 2.29^{b}$ & $30.15 \pm 2^{b}$ & $31.25 \pm 2.23^{b}$ & $35.2 \pm 1.8^{a}$ \\
\hline Lymphocytes (\%) & $66.55 \pm 3.4^{\mathrm{a}}$ & $65.8 \pm 2.4^{\mathrm{a}}$ & $64.6 \pm 3.1^{\mathrm{a}}$ & $61.25 \pm 2.7^{b}$ \\
\hline Monocytes (\%) & $3.4 \pm 0.83^{a}$ & $3.35 \pm 0.7^{a}$ & $3.4 \pm 0.9^{a}$ & $3.05 \pm 0.73^{\mathrm{a}}$ \\
\hline Eosinophils (\%) & $1.0 \pm 0.61^{\mathrm{a}}$ & $0.7 \pm 0.53^{a}$ & $0.75 \pm 0.6^{a}$ & $0.5 \pm 0.55^{a}$ \\
\hline
\end{tabular}

The immunological parameters of rainbow trout are shown in Table 3. Based on the results, the highest levels of immunoglobulin M, lysozyme, C3 (47.25 mg mL $\left.{ }^{-1}\right), \mathrm{C} 4, \mathrm{ACH} 50$ and total immunoglobulin (28.7 $\mathrm{mg} \mathrm{mL}^{-1}$ ) were obtained in $2 \%$ beta-glucan treatment, which showed a significant difference with other treatments $(P<0.05)$. Improvement of immunity in beta-glucan treatments was observed better than the control group. The biochemical parameters of rainbow trout in different treatments are presented in Table 4. The results showed that the amounts of albumin $\left(2.81 \mathrm{~g} \mathrm{dL}^{-1}\right)$ and total protein $\left(3.98 \mathrm{~g} \mathrm{dL}^{-1}\right)$ in 1 and $2 \%$ beta-glucan treatments were significantly higher than $0.5 \%$ beta-glucan and control group. 
Table 3

Immunological parameters of rainbow trout fed diets containing different levels of $\beta$ glucan for 56 days.

\begin{tabular}{|c|c|c|c|c|}
\hline Parameters & Control & $0.5 \%$ & $0.1 \%$ glucan & $0.2 \%$ glucan \\
\hline $\operatorname{lgM}\left(\mathrm{mg} \mathrm{dL}^{-1}\right)$ & $32.7 \pm 2.13^{d}$ & $41.9 \pm 3.2^{c}$ & $47.7 \pm 2.14^{\mathrm{b}}$ & $54.7 \pm 3.8^{a}$ \\
\hline Lysozyme (units $\mathrm{mL}^{-1}$ ) & $38.14 \pm 2.1^{c}$ & $44.7 \pm 1.8^{b}$ & $45.7 \pm 2.4^{b}$ & $59.7 \pm 2.55^{a}$ \\
\hline C3 $\left(\mathrm{mg} \mathrm{mL}^{-1}\right)$ & $28.4 \pm 3.1^{c}$ & $36.24 \pm 2.9^{b}$ & $39.14 \pm 1.8^{b}$ & $47.25 \pm 2.1^{\mathrm{a}}$ \\
\hline $\mathrm{C} 4\left(\mathrm{mg} \mathrm{mL}^{-1}\right)$ & $8.6 \pm 1.1^{c}$ & $8.8 \pm 1.2^{c}$ & $10.9 \pm 1.8^{b}$ & $13.4 \pm 1.5^{\mathrm{a}}$ \\
\hline ACH50 (units $\mathrm{mL}^{-1}$ ) & $59.7 \pm 2.1^{\mathrm{c}}$ & $88.7 \pm 3.8^{b}$ & $95.7 \pm 3.4^{b}$ & $109.4 \pm 2.85^{\mathrm{a}}$ \\
\hline Total lg (mg mL $\left.\mathrm{mL}^{-1}\right)$ & $15.4 \pm 1.2^{d}$ & $18.1 \pm 2.0^{c}$ & $23.5 \pm 1.4^{b}$ & $28.7 \pm 2.25^{a}$ \\
\hline
\end{tabular}

Table 4

Biochemical parameters of rainbow trout in different treatments

\begin{tabular}{|c|c|c|c|c|}
\hline Parameters & Control & $0.5 \%$ & $0.1 \%$ glucan & $0.2 \%$ glucan \\
\hline Globulin $\left(\mathrm{g} \mathrm{dL}^{-1}\right)$ & $1.05 \pm 0.23^{a}$ & $1.14 \pm 0.25^{a}$ & $1.19 \pm 0.22^{\mathrm{a}}$ & $1.17 \pm 0.15^{\mathrm{a}}$ \\
\hline Albumin $\left(\mathrm{g} \mathrm{dL}^{-1}\right)$ & $2.45 \pm 0.17^{b}$ & $2.4 \pm 0.15^{b}$ & $2.74 \pm 0.2^{\mathrm{a}}$ & $2.81 \pm 0.13^{a}$ \\
\hline Total Protein $\left(\mathrm{g} \mathrm{dL}^{-1}\right)$ & $3.5 \pm 0.18^{b}$ & $3.54 \pm 0.2^{b}$ & $3.93 \pm 0.2^{\mathrm{a}}$ & $3.98 \pm 0.14^{\mathrm{a}}$ \\
\hline
\end{tabular}

\section{Discussion}

\subsection{Growth performance}

Immunostimulants such as $\beta$-glucans improve aquaculture production, positively affect fish farming, modify some hematological and immunological parameters (Sánchez-Martínez et al. 2017). In the current research, growth performance and survival rate in treatments of 1 and $2 \%$ beta-glucan were significantly higher compared to 0.5 and $0 \%$ of beta-glucan treatments. Regarding the effect of betaglucan on growth performance, the results of this study are consistent with the results of other researchers. Misra et al. (2006) showed that oral administration of beta-glucan at $540 \mathrm{mg} \mathrm{kg}^{-1}$ for 56 days had a positive effect on growth, immunity and survival rate of Indian carp fry. A significant increase in growth performance with oral beta-glucan administration in Snapper (Cook et al. 2003), Monodon shrimp (Chang et al. 2000), Koi carp (Lin et al. 2011) and rainbow trout (Ji et al. 2020) has been reported. 
In the gut, beta-glucans are broken down by beta-glucanase to facilitate the growth of bacteria that utilize amino acids, which leads to better use of proteins by fish. (López et al. 2003).

Oligosaccharides are a good source of nutrients for the growth and activity of bacteria in the gastrointestinal tract such as lactic acid bacteria, lactobacilli and bifidobacteria and are used as an energy source by lactic acid bacteria (Staykov et al. 2007). In addition, the most important ultimate product of metabolism carbohydrate compounds such as beta-glucan are short-chain fatty acids that are absorbed through the intestinal epithelium and, in addition to providing an energy source for the host, improve nutrient uptake and increase growth (Waché et al. 2006). Studies have shown that prebiotics like mannan oligosaccharide and beta-glucan cause the production of hepatic glucose, which provides energy for metabolism of body tissues and ultimately improves intestinal function by creating the appropriate conditions for the activity of lactic acid bacteria in the gut (Andrews et al. 2009). Improving the survival rate of fish fed on beta-glucan, especially in $1 \%$ and $2 \%$ treatments, may be related to improving the immune status of fish (Couso et al. 2003, Dalmo and Bøgwald 2008), which is in consistent with previous research on rainbow trout (Yarahmadi et al. 2016).

In the present study, the highest feed conversion ratio was observed in the control group, which shows that the presence of beta-glucan in the diet of rainbow trout reduces the feed conversion ratio. As a supplement in salmon diets, beta-glucan is likely to affect the diversity and abundance of intestinal microbes, and these microbiota are essential for improving growth function, survival and nutritional function (Hoseinifar et al., 2015).

\subsection{Hematological parameters}

Blood parameters are essential tools for assessment of the physiological stress response and general health conditions of fish during nutritional and environmental changes

The results of the effect of different nutritional strategies with beta-glucan showed that the highest and lowest red blood cell counts were observed in the diet treated with $2 \%$ beta-glucan and the control group, respectively. Regarding the amounts of hemoglobin and hematocrit, the lowest amount was observed in the control group. Fish red blood cell and hemoglobin counts change significantly with seasonal changes, sexual cycle and other physiological factors (Krajnović-Ozretić et al. 1991). Due to the constant environmental conditions and fish, the presence of beta-glucan in the diet affected the hemoglobin concentration. An increase in red blood cell count was observed in $2 \%$ beta-glucan treatment. It is possible that immunostimulants increase metabolism in fish, so that the number and oxygen carrying capacity of red blood cells enhance (Irianto and Austin 2002). Feeding Oscar fish (Astronotus ocellatus) with yeast significantly increases the number of red blood cells (Firouzbakhsh et al., 2011), which is consistent with the results of the present study.

RBC counts in the blood of fish fed on diets supplemented with immunostimulants were higher, indicating that the fish's immune functions were improved, their defensive mechanisms against pathogens were activated, and their health was improved (Talpur et al., 2012; Adorian et al., 2018). 
In the control group, a lower hematocrit percentage may indicate they are more susceptible to stress induced by experimental management or the pathogenic load naturally present in the culture environment (Tavares-Dias and Moraes, 2004; Mohammadian et al., 2019).

The study also demonstrated this by analyzing other blood variables. It is important to remember that hemoglobin is a vital component of blood and serves as an oxygen transport system for the body. However, it should be noted that the levels of hemoglobin were highest at $2 \%$ beta-glucan. Its increased content indicates that fish receive more oxygen, which in turn enhances fish welfare (Talpur et al., 2012).

This indicates that beta-glucan enhances the availability of oxygen in fish blood, leading to beneficial health effects.

In the present study, the presence of beta-glucan in different treatments caused a significant increase in white blood cell population, especially blood neutrophils, compared to the control group, but no significant difference was observed in the population of monocytes and eosinophils. Jeney et al. (1997) found that the inclusion of beta-glucan in the diet of rainbow trout significantly increased the population of blood neutrophils and decreased lymphocytes. When beta-glucans bind to beta-glucan receptors in macrophages and neutrophils, they produce oxygen free radicals and increase the antioxidant activity of enzymes, thereby enhancing immunity, anti-stress activity, and enhancing the invasion of pathogens (Kim et al. 2009).

Alternative immune responses, in the absence of specific opsonization, could depend on the presence of mannose receptors and toll-like receptors (TLRs) in microbes, which bind to mannose and glucans, leading to enhanced phagocytic and bactericidal abilities in phagocytes and neutrophils (Rebl et al., 2009).

Since WBCs are considered to be the first line of defense against environmental stress or pathogens, an increase in the number of them in fish fed with probiotics may reflect stimulation of the innate immune system (Misra et al., 2006). The proportion of leukocytes increased in Oreochromis niloticus (Ferguson et al., 2010) and O. Mykiss (Merrifield et al., 2011) fed with immunostimulants supplemented diets.

\section{Immunological and biochemical parameters}

Herbal medicines are among the immunostimulants that activate the immune cells by affecting the immune system of fish and lead to increased macrophage cell activity, phagocytic cells (neutrophils and monocytes), lymphocyte count, serum immunoglobulins and lysozyme activity. The use of these substances is an effective tool to increase growth indices, immune system capacity and resistance of fish to common diseases (Hoseinifar et al. 2010). In the current research, a significant difference was observed in the values of immune parameters, so that the highest levels of IgM, Lysozyme, C3, C4 and $\mathrm{ACH} 50$ were observed in treatment with $2 \%$ beta-glucan, which shows that adding beta-glucan to the diet improves immunity in trout. Ai et al. (2007) examined the effects of beta-glucan on growth and innate 
immunity indices in Pseudosciaena crocea fingerlings. The results of their study showed that $0.09 \%$ of glucan in the diet has the best effect on immunity, but immunity was not significantly different in the control group and $0.18 \%$. Moreover, Zhu et al. (2012) reported that channel catfish Ictalurus punctatus immune system improved through the phagocytic activity increment owing to feed supplemented $(0.3 \%)$ with compounds containing at least of $25 \%$ of $\beta-1,3 / 1,6$ glucans.

Studies have indicated that $\beta$-1,3-glucan can modulate innate immunity in 0. Mykiss (Diao et al., 2013; Mohammadi et al., 2019) which agrees with what we observed in the present investigation.

The improvement of the immune system in fish fed with a $\beta-1,3-$ glucan diet could be attributable to lactic acid-producing bacteria (LAB) fermenting in the large intestine or colon, enhancing their relative populations, elevated health status and increased colonization of the LAB compared to the control diets.

Based on the results of the present study, a significant rise in serum proteins (albumin and total) was observed in the treatments fed with beta-glucan 1 and 2 which may be related to the production of immunoglobulin. In fish fed higher levels of beta-glucan in the diet, higher levels of albumin and total protein were observed. Total plasma protein is a dependent parameter for assessing the physiological status of fish and is a diagnostic factor. Total protein and albumin levels can indicate the nutritional status and health of fish (Svetina et al. 2002). Increases in protein and albumin levels reflect an improvement in innate immunity; in other words, increases in total protein and albumin concentrations may be due to stronger nonspecific reactions in fish (Tavares-Dias and Moraes 2007). In the present study, the increase in total protein in treatments containing 1 and $2 \%$ beta-glucan could indicate proper function of the liver, kidneys and aquatic gastrointestinal tract. These results are in accordance with reports of previous researchers who reported that immunostimulants increased total serum protein, albumin and globulin levels in different fish species (Newaj-Fyzul et al., 2007; Sharifuzzaman et al., 2010; Mohammadian et al., 2019).

In conclusion, this study showed that the presence of beta-glucan at the level of $2 \%$ in the diet of rainbow trout improves growth performance, blood and biochemical parameters. Therefore, it is recommended to use beta-glucan in the diet of rainbow trout to improve production performance.

Likewise, $0.2 \%$ of $\beta$-glucan supplementation is sufficient to stimulate the nonspecific immune system of rainbow trout and has a positive effect on parameters such as WBC count and neutrophil activity. Further research is needed on $\beta-1,3 / 1,6$-glucan activity and challenge of fish against infectious pathogens.

\section{Declarations}

Funding: This research is not financially supported

Conflict of interests /Competing interests: The authors declare that they have no conflict of interest.

Ethics approval/declarations: All applicable intuitional guidelines for care and use of fish were followed by the authors. 
Consent to participate: all authours are agree to participate

Consent for publication: all authours are agree to publication

Availability of data and materials (Data transparency): All the data related to the manuscript are genuine and available with us.

\section{Code availability:-}

Authors' contribution: All the authors of the manuscript made significant contribution in the current study. Mohammad Hossein Khanjani: Conception and design of study, Acquisition of data, Analysis and interpretation of data, Drafting the manuscript. Gholamreza Ghaedi: Conception and design of study, Acquisition of data, Analysis and interpretation of data. Moslem Sharifinia: Conception and design of study, Acquisition of data, Analysis and interpretation of data, Revising the manuscript

\section{References}

1. Adorian TJ, Jamali H, Farsani HG, Darvishi P, Hasanpour S, Bagheri T, Roozbehfar, R., 2018. Effects of probiotic bacteria Bacillus on growth performance, digestive enzyme activity, and hematological parameters of Asian sea bass, Lates calcarifer(Bloch), Probiotics Antimicrob Proteins. 11(1):248255.

2. Ai, Q., K. Mai, L. Zhang, B. Tan, W. Zhang, W. Xu, and H. Li. 2007. Effects of dietary $\beta-1,3$ glucan on innate immune response of large yellow croaker, Pseudosciaena crocea. Fish \& shellfish immunology 22:394-402.

3. Amar, E. C., V. Kiron, S. Satoh, N. Okamoto, and T. Watanabe. 2000. Effects of dietary Bcarotene on the immune response of rainbow trout Oncorhynchus mykiss. Fisheries Science 66:1068-1075.

4. Andrews, S. R., N. P. Sahu, A. K. Pal, and S. Kumar. 2009. Haematological modulation and growth of Labeo rohita fingerlings: effect of dietary mannan oligosaccharide, yeast extract, protein hydrolysate and chlorella. Aquaculture research 41:61-69.

5. Chang, C.-F., H.-Y. Chen, M.-S. Su, and I.-C. Liao. 2000. Immunomodulation by dietary $\beta-1,3$-glucan in the brooders of the black tiger shrimp Penaeus monodon. Fish \& shellfish immunology 10:505-514.

6. Chebanov, M., and R. Billard. 2001. The culture of sturgeons in Russia: production of juveniles for stocking and meat for human consumption. Aquatic Living Resources 14:375-381.

7. Cook, M. T., P. J. Hayball, W. Hutchinson, B. F. Nowak, and J. D. Hayball. 2003. Administration of a commercial immunostimulant preparation, EcoActiva ${ }^{\mathrm{Tm}}$ as a feed supplement enhances macrophage respiratory burst and the growth rate of snapper (Pagrus auratus, Sparidae (Bloch and Schneider)) in winter. Fish \& shellfish immunology 14:333-345.

8. Couso, N., R. Castro, B. Magariños, A. Obach, and J. Lamas. 2003. Effect of oral administration of glucans on the resistance of gilthead seabream to pasteurellosis. Aquaculture 219:99-109. 
9. Dalmo, R. A., and J. Bøgwald. 2008. B-glucans as conductors of immune symphonies. Fish \& shellfish immunology 25:384-396.

10. Dawood, M. A., A. E. S. Metwally, M. E. El-Sharawy, A. M. Atta, Z. I. Elbialy, H. M. Abdel-Latif, and B. A. Paray. 2020b. The role of $\beta$-glucan in the growth, intestinal morphometry, and immune-related gene and heat shock protein expressions of Nile tilapia (Oreochromis niloticus) under different stocking densities. Aquaculture 523:735205.

11. Dawood, M. A., S. E. Abdo, M. S. Gewaily, E. M. Moustafa, M. S. SaadAllah, M. F. AbdEI-Kader, A. H. Hamouda, A. A. Omar, and R. A. Alwakeel. 2020a. The influence of dietary $\beta$-glucan on immune, transcriptomic, inflammatory and histopathology disorders caused by deltamethrin toxicity in Nile tilapia (Oreochromis niloticus). Fish \& shellfish immunology 98:301-311.

12. Demers, N. E., and C. J. Bayne. 1997. The immediate effects of stress on hormones and plasma lysozyme in rainbow trout. Developmental \& Comparative Immunology 21:36.

13. Diao, J., Ye, H.B., Yu, X.Q., Fan, Y., Xu, L., Li, T.B., Wang, Y.Q., 2013. Adjuvant and immunostimulatory effects of LPS and $\beta$-glucan on immune response in Japanese flounder (Paralichthys olivaceus). Vet Immunol Immunopathol. 56(3-4):167-175.

14. Doumas, B. T., W. A. Watson, and H. G. Biggs. 1997. Albumin standards and the measurement of serum albumin with bromcresol green. Clinica chimica acta 258:21-30.

15. Ferguson R.M.W, Merrifield, D.L., Harper, G.M., Rawling, M.D., Mustafa, S., Picchietti, S., Balcázar, J.L., Davies, S.J., 2010. The effect of Pediococcus acidilactici on the gut microbiota and immune status of on-growing red tilapia (Oreochromis niloticus). J Appl Microbiol. 109(3):851-862.

16. Firouzbakhsh, F., F. Noori, M. K. Khalesi, and K. Jani-Khalili. 2011. Effects of a probiotic, protexin, on the growth performance and hematological parameters in the Oscar (Astronotus ocellatus) fingerlings. Fish physiology and biochemistry 37:833-842.

17. Ghaedi, G., S. Keyvanshokooh, H. M. Azarm, and M. Akhlaghi. 2015. Effects of dietary $\beta$-glucan on maternal immunity and fry quality of rainbow trout (Oncorhynchus mykiss). Aquaculture 441:78-83.

18. Haghighi, M., Sharif Rohani, M., 2013. The effects of powdered ginger(Zingiber officinale) on the haematological and immunological parameters of rainbow trout Oncorhynchus mykiss. Journal of Medicinal Plant and Herbal Therapy Research, 1, 8-12.

19. Herre, J., Gordon, S., Brown, G. D., 2004. Dectin- 1 and its role in the recognition of $\beta$-glucans by macrophages. Molecular immunology 40:869-876.

20. Hoseinifar, S. H., Zare, P., Merrifield, D. L., 2010. The effects of inulin on growth factors and survival of the Indian white shrimp larvae and postlarvae (Fenneropenaeus indicus). Aquaculture research 41:e348-e352.

21. Hoseinifar, S.H., Eshaghzadeh, H., Vahabzadeh, H., Peykaran Mana, N., 2015. Modulation of growth performances, survival, digestive enzyme activitie and intestinal microbiota in common carp (Cyprinus carpio) larvae using short chain fructooligosaccharide. Aquaculture research, 47(10):32463253. 
22. Houston, A. 1990. Blood and circulation/Methods for fish biology. NY.: Amer. Fish. Society. Jain NC (1986). Schalm's veterinary hematology. Lea \& Febiger, Philadelphia:21-62.

23. Hrubec, T. C., S. A. Smith, and J. L. Robertson. 2001. Age-related changes in hematology and plasma chemistry values of hybrid striped bass (Morone chrysopsx Morone saxatilis). Veterinary Clinical Pathology 30:8-15.

24. Irianto, A., Austin, B., 2002. Probiotics in aquaculture. Journal of fish diseases 25:633-642.

25. Jeney, G., M. Galeotti, D. Volpatti, Z. Jeney, and D. P. Anderson. 1997. Prevention of stress in rainbow trout (Oncorhynchus mykiss) fed diets containing different doses of glucan. Aquaculture 154:1-15.

26. Ji, L., G. Sun, X. Li, and Y. Liu. 2020. Comparative transcriptome analysis reveals the mechanism of $\beta$-glucan in protecting rainbow trout (Oncorhynchus mykiss) from Aeromonas salmonicida infection. Fish \& shellfish immunology 98:87-99.

27. Khanjani, M. H., and M. Sharifinia. 2020. Biofloc technology as a promising tool to improve aquaculture production. Reviews in Aquaculture 12:1836-1850.

28. Khanjani, M. H., M. Alizadeh, and M. Sharifinia. 2021a. Effects of different carbon sources on water quality, biofloc quality, and growth performance of Nile tilapia (Oreochromis niloticus) fingerlings in a heterotrophic culture system. Aquaculture International 29:307-321.

29. Khanjani, M. H., M. Sharifinia, and S. Hajirezaee. 2020b. Effects of different salinity levels on water quality, growth performance and body composition of Pacific white shrimp (Litopenaeus vannamei Boone, 1931) cultured in a zero water exchange heterotrophic system. Annals of Animal Science 20:1471-1486.

30. Khanjani, M.H., Alizadeh, M., Mohammadi, M., Sarsangi Aliabad, H., 2021b. 'Biofloc system applied to Nile tilapia (Oreochromis niloticus) farming using different carbon sources: growth performance, carcass analysis, digestive and hepatic enzyme activity. Iranian Journal of Fisheries Sciences, 20(2); 490- 513.

31. Khanjani, M.H., Alizadeh, M., Mohammadi, M., Sarsangi Aliabad, H., 2021c. The effect of adding molasses in different times on performance of Nile tilapia (Oreochromis niloticus) raised in a lowsalinity biofloc system. Annals of Animal Scienses, DOI: https://doi.org/10.2478/aoas-2021-0011.

32. Khanjani, M.H., Sharifinia, M., 2021d. Production of Nile tilapia Oreochromis niloticus reared in a limited water exchange system: The effect of different light levels. Aquaculture, 542, 736912.

33. Kim, Y.-S., F. Ke, and Q.-Y. Zhang. 2009. Effect of $\beta$-glucan on activity of antioxidant enzymes and Mx gene expression in virus infected grass carp. Fish \& shellfish immunology 27:336-340.

34. Krajnović-Ozretić, M., B. Ozretić, and I. Šterbić. 1991. Hematological and biochemical characteristics of reared sea bass (Dicentrarchus labrax L.(.

35. Kruger, N. J. 2009. The Bradford method for protein quantitation. The protein protocols handbook:1724.

36. Kumar, S., N. Sahu, A. Pal, D. Choudhury, S. Yengkokpam, and S. Mukherjee. 2005. Effect of dietary carbohydrate on haematology, respiratory burst activity and histological changes in L. rohita juveniles. Fish \& shellfish immunology 19:331-344. 
37. Lin, S., Y. Pan, L. Luo, and L. Luo. 2011. Effects of dietary $\beta$-1, 3-glucan, chitosan or raffinose on the growth, innate immunity and resistance of koi (Cyprinus carpio koi). Fish \& shellfish immunology 31:788-794.

38. López, N., G. Cuzon, G. Gaxiola, G. Taboada, M. Valenzuela, C. Pascual, A. Sánchez, and C. Rosas. 2003. Physiological, nutritional, and immunological role of dietary $\beta$ 1-3 glucan and ascorbic acid 2monophosphate in Litopenaeus vannamei juveniles. Aquaculture 224:223-243.

39. Meena, D., P. Das, S. Kumar, S. Mandal, A. Prusty, S. Singh, M. Akhtar, B. Behera, K. Kumar, and A. Pal. 2013. Beta-glucan: an ideal immunostimulant in aquaculture (a review). Fish physiology and biochemistry 39:431-457.

40. Merrifield, D.L., Bradley, G., Harper, G.M., Baker, R.T.M., Munn, C.B., Davies, S.J., 2011. Assessment of the effects of vegetative and lyophilized Pediococcus acidilactici on growth, feed utilization, intestinal colonization and health parameters of rainbow trout (Oncorhynchus mykiss Walbaum). Aquac Nutr. 17(1):73-79.

41. Misra, C. K., B. K. Das, S. C. Mukherjee, and P. Pattnaik. 2006. Effect of multiple injections of $\beta$-glucan on non-specific immune response and disease resistance in Labeo rohita fingerlings. Fish \& shellfish immunology 20:305-319.

42. Misra, C.K., Das, B.K., Mukherjee, S.C., Pattnaik, P., 2006. Effect of long term administration of dietary $\beta$-glucan on immunity, growth and survival of Labeo rohita fingerlings. Aquaculture. 255(1-4):82-94.

43. Mohammadian, T., Mosavi, M., Alishahi, M., Khosravi, M., 2019. Effects of dietary $\beta$-1,3-glucan and host gut-derived probiotic bacteria on hemato-immunological indices and gut microbiota of juvenile rainbow trout (Oncorhynchus mykiss). Iranian Journal of Veterinary Science and Technology. 11(2): 45-58.

44. Mokhbatly, A.-A. A., D. H. Assar, E. W. Ghazy, Z. Elbialy, S. A. Rizk, A. A. Omar, A. Y. Gaafar, and M. A. Dawood. 2020. The protective role of spirulina and $\beta$-glucan in African catfish (Clarias gariepinus) against chronic toxicity of chlorpyrifos: hemato-biochemistry, histopathology, and oxidative stress traits. Environmental Science and Pollution Research 27:31636-31651.

45. Newaj-Fyzul, A., Adesiyun, A.A., Mutani, A., Ramsubhag, A., Brunt, J., Austin, B., 2007. Bacillus subtilis AB1 controls Aeromonas infection in rainbow trout (Oncorhynchus mykiss, Walbaum). J Appl Microbiol. 103(5):1699-1706.

46. Pilarski, F., C. A. Ferreira de Oliveira, F. P. B. Darpossolo de Souza, and F. S. Zanuzzo. 2017. Different $\beta$-glucans improve the growth performance and bacterial resistance in Nile tilapia. Fish \& shellfish immunology 70:25-29.

47. Puangkaew, J., V. Kiron, T. Somamoto, N. Okamoto, S. Satoh, T. Takeuchi, and T. Watanabe. 2004. Nonspecific immune response of rainbow trout (Oncorhynchus mykiss Walbaum) in relation to different status of vitamin E and highly unsaturated fatty acids. Fish \& shellfish immunology 16:2539.

48. Ranjbar, M., M. Ghorbanpoor, R. Peyghan, M. Mesbah, and M. Razi Jalali. 2010. Effects of dietary Aloe vera on some specific and nonspecific immunity in the common carp (Cyprinus carpio). Iranian 
Journal of Veterinary Medicine 4.

49. Ranzani-Paiva, M. J. T., C. M. Ishikawa, A. C. d. Eiras, and V. R. d. Silveira. 2004. Effects of an experimental challenge with Mycobacterium marinum on the blood parameters of Nile tilapia, Oreochromis niloticus (Linnaeus, 1757). Brazilian Archives of Biology and Technology 47:945-953.

50. Rebl, A., Goldammer, T., Seyfert, H., 2009. Toll-like receptor signaling in bony fish. Vet Immunol Immunopathol. 134(3-4):139-150.

51. Sánchez-Martínez, J. G., J. L. Rábago-Castro, M. d. I. L. Vázquez-Sauceda, R. Pérez-Castañeda, Z. Blanco-Martínez, and F. Benavides-González. 2017. Effect of $\beta$-glucan dietary levels on immune response and hematology of channel catfish Ictalurus punctatus juveniles. Latin american journal of aquatic research 45:690-698.

52. Sharifuzzaman, S.M., Austin, B., 2010. Kocuria SM1 Controls vibriosis in rainbow trout (Oncorhynchus mykiss, Walbaum). J Appl Microbiol. 108(6):2162-2170.

53. Sheikhzadeh, N., Nofouzi, K., Delazar, A., Khani Oushani, A., 2011. Immunomodulatory effects of decaffeinated green tea (Camellia sinensis) on the immune system of rainbow trout (Oncorhynchus mykiss). Fish and Shellfish Immunology, 31, 1268-1269.

54. Soltanian, S., E. Stuyven, E. Cox, P. Sorgeloos, and P. Bossier. 2009. Beta-glucans as immunostimulant in vertebrates and invertebrates. Critical reviews in microbiology 35:109-138.

55. Staykov, Y., P. Spring, S. Denev, and J. Sweetman. 2007. Effect of a mannan oligosaccharide on the growth performance and immune status of rainbow trout (Oncorhynchus mykiss). Aquaculture International 15:153-161.

56. Sunyer, J. O., and L. Tort. 1995. Natural hemolytic and bactericidal activities of sea bream Sparus aurata serum are effected by the alternative complement pathway. Veterinary Immunology and Immunopathology 45:333-345.

57. Svetina, A., Ž. Matašin, A. Tofant, and et al. 2002. Haematology and some blood chemical parameters of young carp till the age of three years. Acta Veterinaria Hungarica 50:459-467.

58. Talpur, A.D., Ikhwanuddin, M., 2012. Dietary effects of garlic (Allium sativum) on haematoimmunological parameters, survival, growth,and disease resistance against Vibrio harveyi infection in Asian seabass, Lates calcarifer (Bloch). Aquaculture, 364-365:6-12.

59. Tavares-Dias M, Moraes FR (2004) Hematologia de peixes teleosteos. Villimpress Ribeirao Preto, $p$ 144.

60. Tavares-Dias, M., and F. Moraes. 2007. Haematological and biochemical reference intervals for farmed channel catfish. Journal of Fish Biology 71:383-388.

61. Tokunaka, K., N. Ohno, Y. Adachi, S. Tanaka, H. Tamura, and T. Yadomae. 2000. Immunopharmacological and immunotoxicological activities of a water-soluble $(1 \rightarrow 3)-\beta$-d-glucan, CSBG from Candida spp. International journal of immunopharmacology 22:383-394.

62. Vella, F. 1986. Textbook of clinical chemistry: Edited by N W Tietz. Pp 1919. W B Saunders, Philadelphia. 1986 ISBN 0-7216-8886-1. Biochemical Education 14:146-146. 
63. Waché, Y., F. Auffray, F.-J. Gatesoupe, J. Zambonino, V. Gayet, L. Labbé, and C. Quentel. 2006. Cross effects of the strain of dietary Saccharomyces cerevisiae and rearing conditions on the onset of intestinal microbiota and digestive enzymes in rainbow trout, Onchorhynchus mykiss, fry. Aquaculture 258:470-478.

64. Wei, G., H. Tan, S. Ma, G. Sun, Y. Zhang, Y. Wu, S. Cai, Y. Huang, and J. Jian. 2020. Protective effects of $\beta$-glucan as adjuvant combined inactivated Vibrio harveyi vaccine in pearl gentian grouper. Fish \& shellfish immunology 106:1025-1030.

65. Yan, Y., X. Huo, T. Ai, and J. Su. 2020. $\beta$-glucan and anisodamine can enhance the immersion immune efficacy of inactivated Cyprinid herpesvirus 2 vaccine in Carassius auratus gibelio. Fish \& shellfish immunology 98:285-295.

66. Yang, G., H. Qiu, R. Yu, L. Xiong, Q. Yan, C. Wen, and M. Peng. 2021. Dietary supplementation of $\beta-$ glucan, inulin and emodin modulates antioxidant response and suppresses intestinal inflammation of grass carp (Ctenopharyngodon idellus). Animal Feed Science and Technology 272:114789.

67. Yarahmadi, P., H. Kolangi Miandare, and S. Hoseinifar. 2016. Haemato-immunological and serum biochemical parameters, intestinal histomorphology and growth performance of rainbow trout (Oncorhynchus mykiss) fed dietary fermentable fibre (Vitacel ${ }^{\circledR}$ ). Aquaculture Nutrition 22:1134-1142.

68. Zhu, H., H. Liu, J. Yan, R. Wang, and L. Liu. 2012. Effect of yeast polysaccharide on some hematologic parameter and gut morphology in channel catfish (Ictalurus punctatus). Fish physiology and biochemistry 38:1441-1447. 